\title{
The Determinants of Tourism Demand in Turkey
}

\author{
Musallam Abedtalas, Lokman Toprak \\ Mardin Artuklu University, High School of Tourism and Hotel Management, Turkey \\ Abedtalasmus@gmail.com
}

\begin{abstract}
Using data of the inbound tourist arrivals to Turkey from France, Germany, UK, US, and Netherlands over the period 1986-2012, we applied autoregressive distributed lag (ARDL) approach to test for cointegration, and we estimated long run model and error correction model for tourism demand. The results referred that the most significant factor determines inbound tourist flows are the real per capita income and real effective exchange. We found weak effects for price and financial crisis, but the political events played a strong role differed from country to other. The added value of this article is the estimation of international tourism demand in Turkey using new approach and the newest data for Turkey
\end{abstract}

Keywords: Economics, Econometric, Turkey, tourism demand, ARDL

\section{Introduction}

The temporary movement of people from their living place to another, to meet their social, cultural and psychological needs, like traveling, sightseeing, relaxation, health, education and fun can be defined as tourism Kar et al. (2004). Besides its social and cultural dimensions, that is mostly considered, tourisms economic aspects also has become one of the fastest growing industry of the world economy since the second half of 20 century (Çimat \& Bahar, 2003). Tourism activities also serve as a driving force for development of other sectors as well. Besides the contribution to national income, Tourism also is an important source for foreign currencies, and plays an important role on filling balance of payment deficits. Having the advantage of being one of the highest intensive labors, tourism provides employment opportunities to a large mass of people. In addition tourism maintains to be an effective marketing and advertisement tool for the country. It's observed that, Since the 1950s the economic importance of tourism is apprehended and the activities of this area are encouraged, touristic investments and other related investments that are essential for the development of tourism like transportation has increased rapidly (Ünlüönen \& Tayfan, 2009). Also there is an important specialty for tourism sector, that is the fast recovery from and adjusting to crisis (UNWTO, 2014, P.1-6).

Turkey's active foreign tourism has started to show a significant improvement particularly since the 1980 s, and has become one of the great contributions that provide sources of income for the country. It's providing of foreign currency, while the country was having economic problems, helped to decrease foreign debt and unemployment (Çimat \& Bahar, 2003). The new tourism policy, containing rapid development of infrastructure and incentives in the economy and the tourism industry after the 1990s has led to a rapid rise in tourism revenues. This trend continues in the 2000s. Numerically in the year of 2012 the share of the travel and tourism industry of global GDP was USD 2.05 trillion, which is $2.9 \%$. For Turkey, The industry's contribution to total GDP was around 4\%, USD 32.3 billion. The travel and tourism sector has created 1.9 million jobs. So it is the second largest job source after the public sector. This sector provides 9\% of Turkey's job opportunities. (Investment Support and Promotion Agency of Turkey, 2013, 3-4). In the same year Turkey occupied the sixth first position in the world by the number of international tourist arrivals and the eleventh first position by international tourism receipts(Turkish Hotelier Federation, 2013), this, high arrivals number position and lower receipt position, could be a result, between many factors, of low price policy in tourism sector. Given the importance of tourism to economies, governments and researchers as well as tourism business are interested in the factors that determine tourist flows to a country and the reaction of tourism demand to these factors. Such knowledge is useful for making accurate predictions of tourism demand, the planning of infrastructure and facilities for tourists, and the development of effective tourism policies. This induced researchers to model the demand for tourism using many approaches, quantitative and qualitative. 
In this context, the importance of tourism sector, and the importance of modeling the demand for tourism, especially for Turkey, and as Turkey is placed in unstable area, we try to construct a tourism demand function, which takes into account the macroeconomic factors and some special events. The model constructed in this paper belongs to causal econometric approaches, and based on the classical economic theory, which concentrates on income and price as determinants of the demand for international tourism. As many empirical studies have found that the behavior of tourists may be affected by non-economic factors, we try to assess the impacts of special events of Golf War 1991, Abdullah Öcalan arresting 1999, 9-11, Iraqi invasion 2003, the outbreak of SARS virus 2006, and financial crisis 2008-2009 on the number of international tourist arrivals to Turkey. Numerous studies tried to estimate tourism demand function in Turkey, but, to our knowledge the application of ARDL approach for a set of Turkish data is new. In this paper we are trying to evaluate the relationship between inbound tourism in Turkey and related macroeconomic variables and some special events, for the major tourism markets, with the purpose of providing the interested agents with better understanding of the demand for tourism, in order to make better decisions relating to tourism activities. So the added value of this article is the estimation of international tourism demand for Turkey, for its basic markets, using new approach and the newest data. This paper is organized as follows: the next section reviews empirical literature on tourism demand. Section 3 discusses the empirical methodology employed in this study. The empirical results are presented and discussed in section 4 . The last section is conclusions.

\section{Literature Review}

According to Song et al. (2009, P. 31) the rapid growth of tourism industry globally attracted the interest of researchers since the end of the World War II. And they tried to model the tourism demand to analyze the effects of different factors, and predict the future behavior of the demand. After that many advances took place, theoretically and methodologically. Until the early 1990s, the tourism demand models were just static, which suffered from many problems. The dynamic models, with their merits for long-run and short-run demand elasticity analysis, appeared in med of 1990s. We will concentrate on recent studies that used ARDL and the studies about inbound tourism in Turkey. Wang (2009) used the auto-regression distributed lag model ARDL and Bounds test for studying tourism demand function for Taiwan. Using data for the period of 1996(Q1)- 2006(Q2), he studied the role of macroeconomic variables, such as foreign exchange rates, incomes, relative prices, and transportation costs as determinants of the demand for inbound tourism, in addition to the impacts of some special events. He found long run cointegration relationships between all variables. The short run elasticities of income and foreign exchange rates were both significant and more than $/ 1 /$, but the coefficient of the price was not significant. The effects of special events also were significant. But his study was just for Japan market and it did not estimate the long run equation. Chaitip and Chaiboonsri (2009) also used ARDL approach, and data from 1997(Q1)2005(Q2) to study the short-run and long-run relationships between international tourist arrivals in Thailand and GDP, the price of goods and services, transportation costs, temperature of Thailand, and both the exchange rate and exchange rate risk. The results indicated that the (GDP) of Thailand's major tourist source markets has a positive impact on international visitor arrivals while transportation cost and both exchange rate and exchange rate risk have a negative impact on international visitor arrivals to Thailand, in long run and short run. And the result differed too much between the markets.

Lee "a"(2011) estimated tourism demand elasticities for Hong Kong, from four major markets, using (ARDL) approach to cointegration. The results showed that the permanent income is the most important variable for all markets, but with some differences between countries with the long-run elasticity. The second important variable was price. Ziramba and Moyo (2013) sought to identify the determinants of outbound tourism demand (outbound tourist outflows) in South Africa. They also employed (ARDL) approach to explain the long run and short run relationships. The results indicated that in the long run the real domestic income and the relative prices are significant factors. In the short run, only the relative prices have an impact on outbound tourism demand from South Africa. For turkey the first article about the demand for inbound tourism was Uysal and Crompton (1984). This article studied the demand for tourism in Turkey using factors such as: per capita income, relative prices, relative exchange rate, promotional expenditure, and special events (political unrest) as determinants, for the period 19601980.Analysiswas by least squares multiple regressions. Income, price and exchange rate were found to be important factors but the impact of promotional expenditure was minimal. Akls (1998) examined the relationship between tourism demand for Turkey and national income and relative prices. In determining the relationship, he used a double-logarithmic functional form, for the period of 1980-1993, for 18 markets. In general, the results indicated a positive relationship for national income, and a negative 
relationship for relative prices. But the models in the two previous studies were static without any test for stationary, as it was not common yet. And the special events used only for Germany and Cyprus in Uysal and Crompton (1984).

Karagoz and Saray (2010) studied the factors that control the inflow tourism based on a (static) panel gravity model for the period of 1992-2007, and found that there are positive relationships between the demand for tourism and GDP per capita and population. In this study there is no role for the prices or the special events. Balli et al. (2013) used the same model, (static and dynamic) panel gravity model framework, after adding, special events, price, and trade variables. The application was for 81 source countries for a period between 1995 and 2010. The results indicated that the coefficients of GDP, population, CPI, and Trade volume was significant. In this paper we used ARDL approach to cointegration as used by Wang, (2009), Chitip and Chaiboonsri (2009), Lee"a"(2011), Ziramba and Moyo(2013) and made bound test, for Turkey time series data of inflow tourism from its basic origin developed countries, for the period 1986-2012, with special interest in political and economic negative events. So we used an approach that is not used for Turkey yet, and for different time period, to answer the question of the role of macroeconomic variables and special events in the demand of tourism in turkey.

\section{Data Description and Modelling Approach}

Data description: We used data for our variables from World Bank ${ }^{1}$, except for the number of tourist arrivals we got data from Turkish Ministry of Tourism and Culture ${ }^{2}$. We selected five developed country for our study (Germany, Netherlands, France, UK, and US) as they constitute a big share of sources of tourists to Turkey and because of the availability of data. For the dummy variables, which take the 0 value except in some specific years, we concentrated on Golf War 1991 and the variable takes the value of 1 in 1991, arresting of Abdullah Öcalan 1999 and the variable takes the value of 1 in 1999, 9-11 attacks in New York and the variable takes the value of 1 in 2001, the Iraq invasion and the variable takes the value of 1 in 2003, the outbreak of SARS and the variable takes the value of 1 in 2006, and the financial crisis and the variable takes the value of 1 in 2008-2009.

Modelling approach: According to classical economic theory demand $(\mathrm{A})$ is function for Income $(\mathrm{Y})$ and Prices $(P): A=f(Y, P)$. And the same applies to tourism demand with adding additional variables, for our purpose the tourism demand function takes the form:

$$
\begin{aligned}
& A=a+\beta_{0} Y+\beta_{1} P+\beta_{2} R E E R+ \\
& \beta_{3} D 1+\beta_{4} D 2+\beta_{5} D 3+\beta_{6} D 4+\beta_{7} D 5+\beta_{8} D 6+\varepsilon
\end{aligned}
$$

Where:

A: number of tourist arrival to Turkey

Y: per capita income in the origin country (expected sign positive)

P: price level in Turkey (expected sign negative)

REER: real effective exchange rate in origin country (expected sign negative)

D1: dummy variable represents golf war 1991 (expected sign negative)

D2: dummy variable represents arresting Abdullah Öcalan and the followed political instability 1999 (expected sign negative)

D3: dummy variable represents 9-11-2001 (expected sign negative)

D4: dummy variable represents Iraq invasion 2003(expected sign negative)

D5: dummy variable represents SARS outbreak 2006 (expected sign negative)

D6: dummy variable represents financial crisis 2008-2009(expected sign negative)

$\varepsilon$ : Random error term

Generally two kind of functional forms are used for demand for tourism, linear equation or power equation. The power function is preferred because of: First, it implies that the marginal effects of each independent variable on the dependent variable are not constant, but depend on the value of the variable and all other variables in the demand function. Second the ability of transformation into a linear relationship using logarithms that makes the estimation relatively easy (known as the double-log or log-

\footnotetext{
${ }^{1}$-http://data.worldbank.org/indicator

${ }^{2}$-http://www.kultur.gov.tr/EN,36568/number-of-arriving-departing-visitors-foreigners-and-ci-.html
} 
log model). Third the estimated coefficients are estimates of demand elasticities (Song et al., 2009, P. 910, 37). So we used double-log functional form as the following:

$$
\begin{aligned}
& \ln A=a+\beta_{1} \ln Y+\beta_{2} \ln P+\beta_{3} \ln R E E R+ \\
& \beta_{4} D 1+\beta_{5} D 2+\beta_{6} D 3+\beta_{7} D 4+\beta_{8} D 5+\beta_{9} D 6+\varepsilon
\end{aligned}
$$

As an estimation using OLS may give spurious regression, when the data series are not stationary, the Engle and Granger cointegration approach, could be a good solution for this issue. Using the Error Correction Model (ECM) to estimate tourism demand, gives us many advantages. Among them the capability of the error correction approaches of capturing the long run and short run relationships, while the static Ordinary Least Squares (OLS) approach concentrates on the long-run equilibrium relationship ( Lee, 2011). According to Wang ( 2009), when there are series I(1) and I(0) in the model, the using of traditional cointegration methods, such as the two-stage method, maximum likelihood approximation cointegration, may produce biased results. So he advises using ARDL approach developed by Pesaran et al. (2001) The advantage of using the ARDL model is its ability to detect long-run relationships and solve the small-sample problem whether the series are just first order-integrated, I(1), purely zero orderintegrated, I(0), or a mixture of both (Lee, 2011; Chaitip and Chaiboonsrl , 2009). For our purpose ARDL takes the following form:

$$
\begin{aligned}
& \Delta \ln A_{t}=a+\lambda_{1} \ln A_{t-1}+\lambda_{2} \ln Y_{t-1}+\lambda_{3} \ln P_{t-1}+\lambda_{4} \ln \text { REER }_{t-1}+\sum_{i=1}^{n 1} \beta_{0} \Delta \ln A_{t-i}+\sum_{i=0}^{n 2} \beta_{1} \Delta \ln Y_{t-i}+ \\
& \sum_{i=0}^{n 3} \beta_{2} \Delta \ln P_{t-i}+\sum_{i=0}^{n 4} \beta_{3} \Delta \ln R_{E E R_{t-i}}+\beta_{4} D 1+\beta_{5} D 2+\beta_{6} D 3+\beta_{7} D 4+\beta_{8} D 5+\beta_{8} D 6+\varepsilon_{t}
\end{aligned}
$$

Where : $\Delta$ first differences, $\beta_{i}$ short run relationships, and $\lambda_{i}$ long run relationships.

A general error correction representation of equation (3) is:

$$
\begin{aligned}
& \Delta \ln A_{t}=a+\gamma E C_{t-1}+\sum_{i=1}^{n 1} \beta_{0} \Delta \ln A_{t-i}+\sum_{i=0}^{n 2} \beta_{1} \Delta \ln Y_{t-i}+\sum_{i=0}^{n 3} \beta_{2} \Delta \ln P_{t-i}+\sum_{i=0}^{n 4} \beta_{3} \Delta \ln R E E R_{t-i} \\
& +\beta_{4} D 1+\beta_{5} D 2+\beta_{6} D 3+\beta_{7} D 4+\beta_{8} D 5+\beta_{8} D 6+\varphi_{t}
\end{aligned}
$$

Where $\gamma$ is the coefficient of error correction speed, and is expected to be negative. This coefficient indicates to the speed at which the current differences in tourist arrivals respond to the disequilibrium in the previous period.

Relating to the dependent variable, tourism demand is generally measured by the number of tourists visit the destination country, or by tourists expenditure in the destination country, or by the number of tourist nights spent in the destination (Song et al., 2009, p. 2-3). Demand theory suggests that the best demand variable should be able to measure the quantity of the product demand. So measuring demand in real money terms is better. But often the data is not available. In general data on the tourist arrivals is better alternative as they are more reliable but they are less responsive to the independent variables (Qu and Or, 2006). The majority of studies used tourist arrivals (Munoz, 2007). So we used per capita number of tourist arrivals because of the availability of reliable data for number of arrivals and to take the population of source countries into account $(A=$ number of tourist arrivals from a country in a specific year/population number for the same country in the same year). Commonly the selection of independent variables has often been based on the data availability and the specialties of the study. Also there are many factors prevents us from including all independent variables in the model, such as degree of freedom and multicollinearity (Zhang et al., 2009). Considering the above factors, we chose three economic variables, income (real per capita GDP) in origin country, Price (CPI) in Turkey, and real effective exchange rate (REER) for origin country, and special events. Income is the most important factor. It affects the ability to pay for travel. Results from empirical studies showed that income is an important variable; it is considered to be a key element in the demand for tourism function (Hamadeh and Khoueiri, 2012; Dwyer and Forsyth, 2006). We used real per capita GDP to account for this variable.

Relating to price, commonly the consumer price index (CPI) in a destination country is considered the proxy for the cost of tourism. Prices are also a key element in most of the studies that were included in the 
typical single equation formula. However, it worth noting that relative prices are difficult to determine, and in most studies they were accounted for in indirect ways. The most commonly used reference point for prices was the consumer price index (Hamadeh and Khoueiri, 2012). We used the CPI to represent the price level in Turkey. Exchange rates are often viewed as determinant factors of the tourism demand due to the fact that tourists are more likely to be aware of exchange rates than of living costs and prices of the destination country. Many authors included the exchange rates in their studies, and focused on its significance whether by including the exchange rates between the tourist origin and the individual destination, by tourist origin and an average rate of a basket of destinations, or by composite relative prices (Hamadeh and Khoueiri, 2012). There are other causes of separating exchange rates from relative prices. They are the availability of more reliable data for exchange rates, and the ability of traveler to get information about exchange rates more quickly and easily (Vog, 2008; Vogt and Wittayakorn, 1998). We used real effective exchange rates to account for this variable. In respect of special events, dummy variables are used to account for specific events. These events include political, economic, and natural events. When the traveler chooses the destinations, often he avoids sites of terrorism and seeks places with stable political and natural situations that ensure his safety (Wang, 2009). We expect the most important events that affect tourism demand, during the period 1986-2012, to be: Golf War 1991, the arresting of Kurdish leader Abdullah Öcalan, 9-11, Iraq invasion, SARS outbreak 2006, and financial crisis 2008-2009.

\section{Results}

To use ARDL approach to cointegration the variables must be stationary in the levels or first differences or mixed, or integrated I (0) or (1) or mixed from the two. We preceded ADF (Augmented Dickey-Fuller) and PP (Philips and Perron) tests for stationary to determine the level of integration. And the results for the five countries are labeled in table (1).As we can see from table (1 in the appendix) the whole variables are integrated between I ( 0 ) and I (1), so we can use ARDL. We estimated ARDL model, using general to specific way, by omitting insignificant ones. We chose two period lag for variables to keep enough freedom degree as we have small sample of observations. And we got results shown in table (1). We conducted the Breusch-Godfrey Serial Correlation LM test for the models and found that there is no serial correlation, as in Table (2) panel (a) in the appendix, and CUSUM test for structural stability and found stability, as in figure (1) panel (a) in the appendix. So we conducted the Wald test (table 3 in the appendix) to know whether the variables are cointegrated (or they have long run equilibrium relationships), and we compared the result (calculated F statistic) with the critical values reported in the table (iii) (Asymptotic critical value bounds for the F-statistic Testing for the existence of a level relationships) in Pesaran et al. (2001), and found that the variables are cointegrated, as the calculated values were more than Upper bound critical values. So we can use (OLS) approach to estimate long run relationships between the variables.

As we see in the table (2), we found that the income has expected positive sign, for all markets, and the coefficients are significant, except for USA, which means positive relationship. And its value was more than one (elastic) for France and UK, which refers to tourism to Turkey as luxury good. But it is less than one for Netherlands and Germany and US, may this be a result of the fact that there are so many Turkish migrants in Germany and Netherland, or a result of considering tourism necessary good for the three countries. For price we found unexpected, positive, signs for the coefficients, except for France. Their value were so low, which means inelasticity, and they were not significant for France and US, this may be a result of the fact that many tourists come as groups using tourism agencies which have a high ability of bargaining, and a considerable share of business tourism and relative visit specially for Germany. Relating to REER we found that the coefficients have expected signs, negative, and they were significant with values more than one (elasticity). Which means with higher levels of real effective exchange rates in the origin countries the demand for tourism to Turkey goes down. The highest value for this coefficient was for France, which may be resulted from the high level of substitution between France and Turkey as they have many similarities in this field, for example the two countries are Mediterranean. Considering the special events, D6 is omitted in ARDL model, meaning no effect for financial crisis 2008-2009. For Golf War 1991 D1, their coefficients had expected negative sign and were significant for all origin countries, and its values were the highest between the dummy variables, meaning it was the most important event. This may be a result of the fact that Golf War was international event and these countries participated in this war. Considering Abdullah Öcalan arresting and the followed political instability 1999, D2, it had expected negative and significant coefficients for France , Germany and Netherlands, but it had no role for UK and US, and we expect this difference to be the result of migration relationships and geographic 
closeness. Relating to 9-11 (D3) and Iraq invasion (D4), they had negative and significant coefficients for the US only. We expect this to be a result of US being the more involved country in these events. Regarding to SARS outbreak 2006 (d5), we found insignificant negative coefficient only in the case of France. These results consist with Wang (2009) relating the effect of financial crisis and that the safety of tourists is the key to maintain inbound tourism, but the same is not true for health.

Table 1: ARDL estimation results

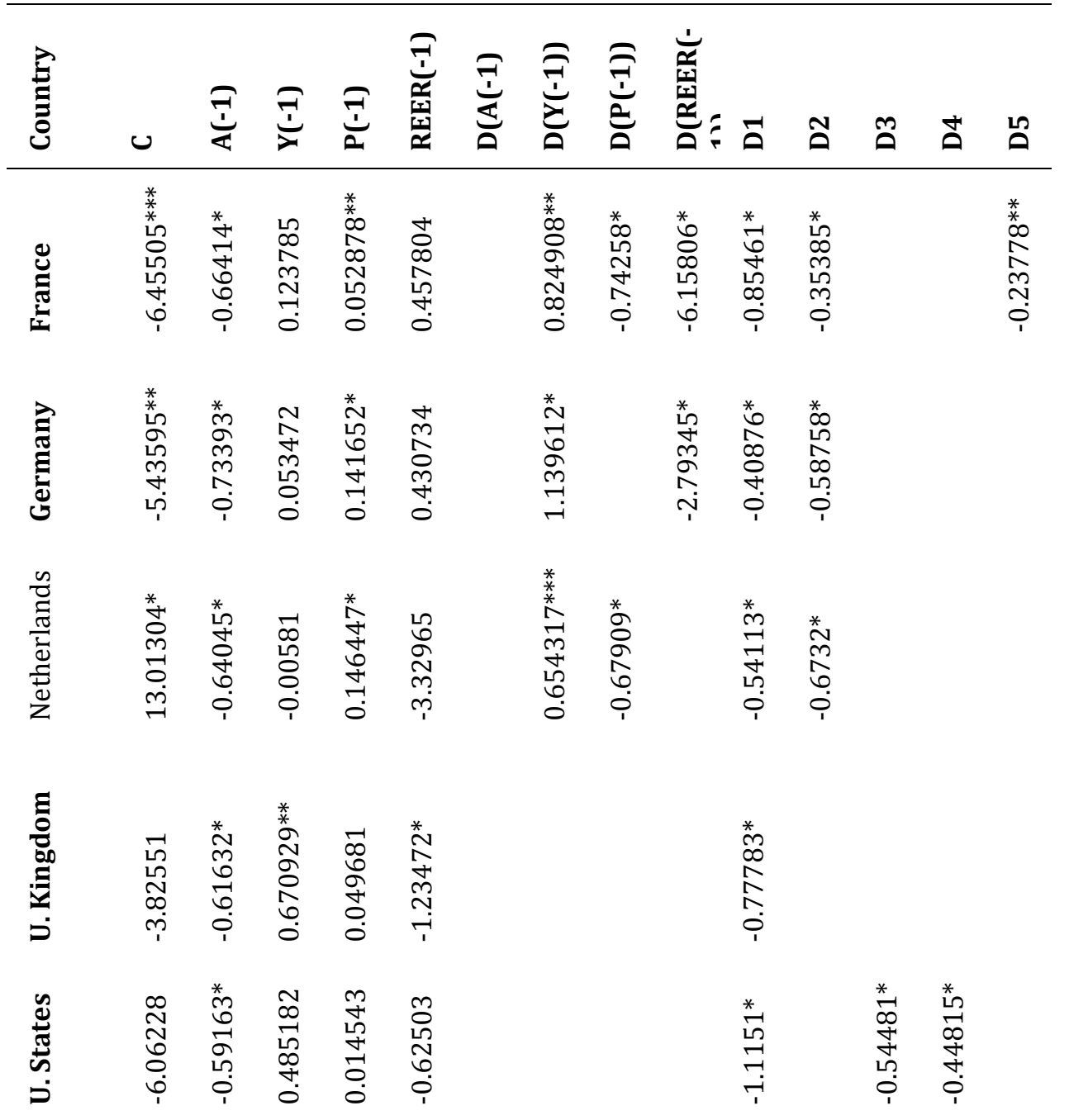

*: significant at $0.01,{ }^{* *}$ significant at 0.09 , and ${ }^{* * *}$ significant at 0.10 , D: difference

Using Ordinary Least Squares (OLS) we estimated the long run demand function, and we found the coefficients displayed in table (2).

The adjusted R-square for the five models were : $0.93,0.97,0.95,0.95$, and 0.88 respectively which means high ability of the models to explain the dependent variable variances which are more than $90 \%$, and for F-statistic (prob) were: $0.00,0.00,0.00,0.00$, and 0.00 which means good fitting for the models. We conducted the Breusch-Godfrey Serial Correlation LM test for the models and found that there is no serial correlation, as in Table (2) panel (b) in the appendix, and CUSUM test for structural stability and found stability, except for Netherlands and UK as in figure (1) panel (b)in the appendix. We estimated general error correction model (ECM), and got the results shown in table (3). As the table (3) shows the error correction coefficients are significant and negative for all origin countries, and their values are less than one, as expected, which indicates to the long run causation between independent and dependent variables. The results indicate that the adjusting of disequilibrium is the fastest in France 55\% yearly, followed by US 49\% yearly, Netherlands 37\% yearly, Germany 35\% yearly, and UK 33\% yearly. 


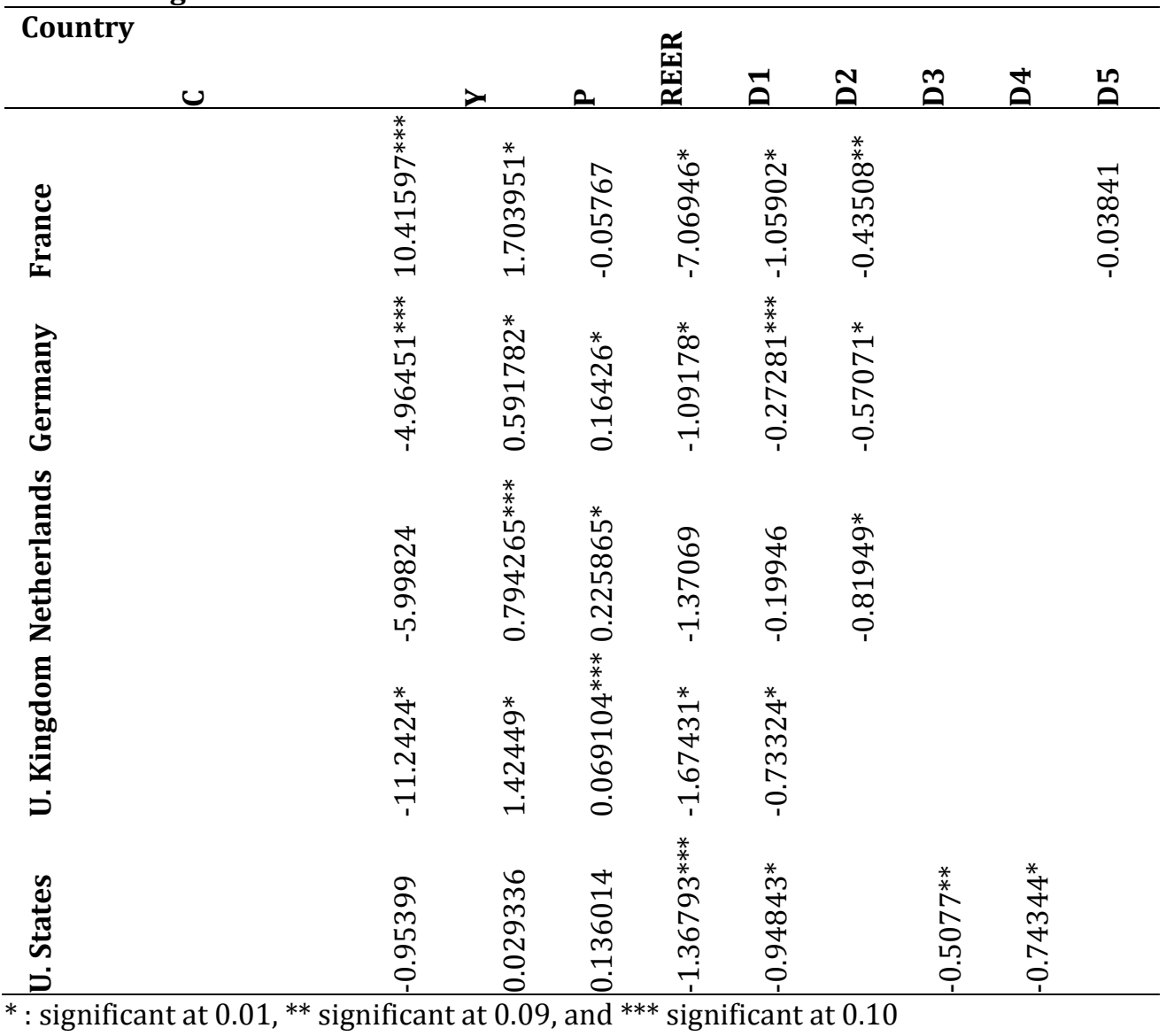

For income, in short run, the coefficients have expected positive signs and they are significant for France and Germany, but with unexpected sign and insignificant for Netherlands. But there is no role for income for UK and US. For price the coefficients got expected sign for France and unexpected sign for Netherlands, with no role for price in the other countries. That can be explained by the same factors as in the long run. For REER the coefficients have expected signs in Germany and France but it is not significant in Germany. For special events they show results as in the long run model with fewer values. Comparing, in general, between the long run and short run models, we find that the coefficients of long run models are bigger than the short run ones. That means higher sensitivity of tourism to its determinants in long run. This supports the idea that tourism is long run activity. This finding is compatible with what reported by Song et al. (2009) that the sensitivity of income and own-price in the long run are greater than their short-run counterparts. These results consist with demand theory. Due to information asymmetry and relatively inflexible budget allocations, it takes time before income changes affect tourism demand.

The adjusted R-square for the five models were : $0.86,0.53,0.40,0.38$, and 0.70 respectively which means the different levels of the ability of models to explain the variances of dependent variable, and for $\mathrm{F}$ statistic (prob) were:0.00, 0.00, 0.00, 0.00, and 0.00 which means good fitting for the models. We conducted the Breusch-Godfrey Serial Correlation LM test for the models and found that there is no serial correlation, as in Table (1) panel (c) in the appendix, and CUSUM test for structural stability and found stability, except for UK as in figure (1) panel (c) in the appendix. To understand the behavior of tourism demand with shocks and innovations we estimated VAR model, and conducted impulse response and variance decomposition. Impulse response functions show the effects of shocks on the adjustment path of the variables. Variance decomposition is another way which considers the contribution of each type of shock to the forecast error variance (Hill et al., 2011). 


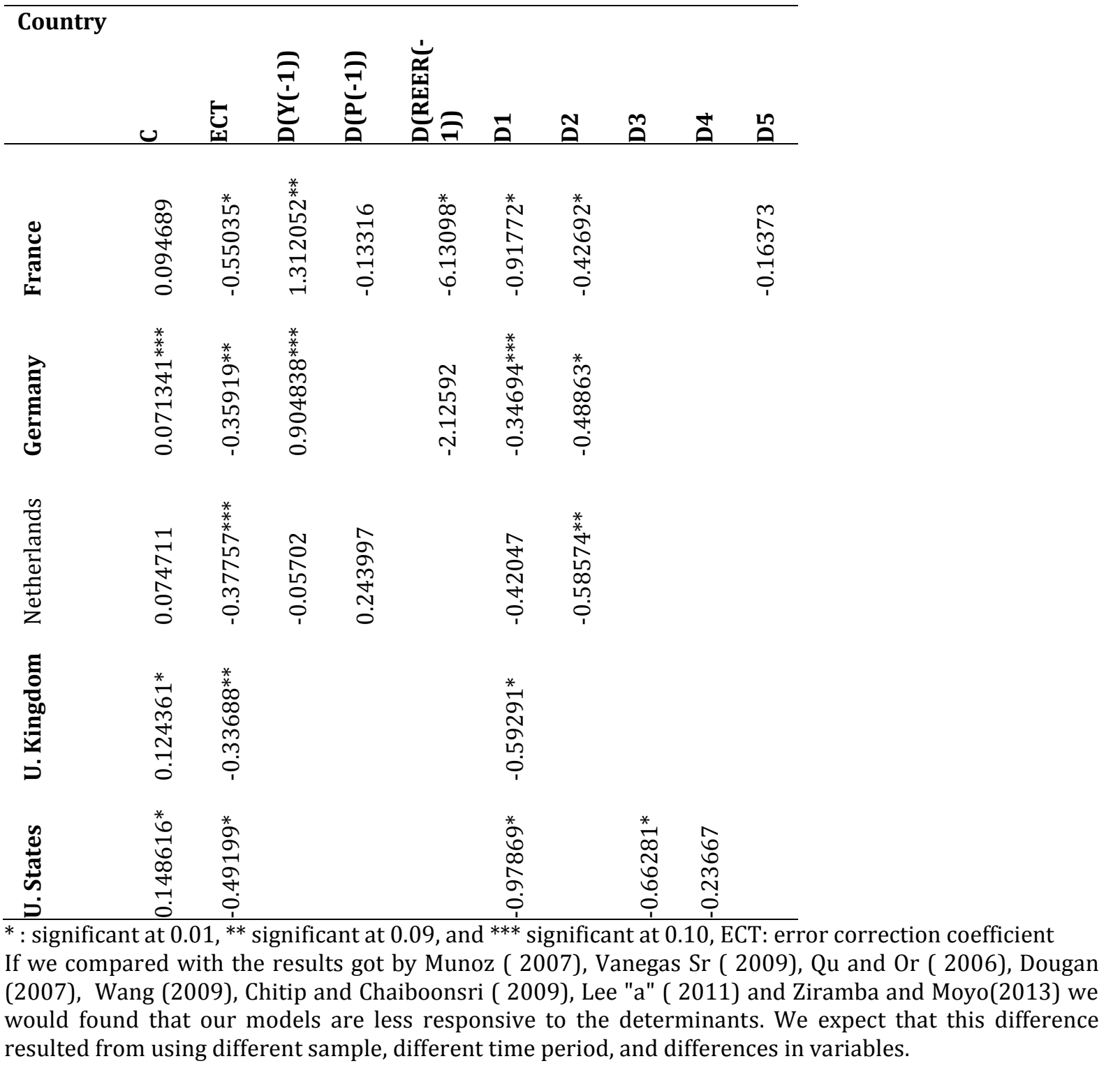

In the figure (2), there is the impulse response. For France, in panel (a), the demand for tourism responds positively to one SD in prices and negatively to one SD in income and REER. The effect generally starts from the first year and reaches its top in the second year and goes down after that. The most powerful reaction is to income. For Germany in panel (b) the demand for tourism responds positively to one SD in prices and income and negatively to one SD in REER in the first three years and positively after that. The effect generally starts from the first year and reaches some of its tops in the second year and goes down and up after that. The most powerful response is to income. Considering Netherlands in panel (c) the demand for tourism responds positively to one SD in prices and negatively to one SD in income and REER. The response starts from the first year and goes up. The most powerful response is to income and price. In panel (d), for UK, the demand for tourism responds positively to one SD in income and negatively to one SD in price and REER. The response starts from the first year and goes up for income, reaches a top in the third year and goes down for price, reaches a top in the fourth year and goes down for REER. The most powerful response is to income and REER. In panel (e), for US, the demand for tourism responds positively to one SD in income and price and REER, but becomes negative in the seventh year for price. The response starts from the first year and goes up for income, reaches a top in the third year for price and REER. The most powerful response is to income. This means that the most important factor in the adjustment path of the demand for tourism after the demand himself is the income.

In table (4) in the appendix there is variance decomposition. In panel (a) for France, we find that after the first year the demand explains $66.3 \%$ of its variance and this share goes down after that. Income explains 
$21.3 \%$ and this share goes down after that. Price explains $10.9 \%$ and this share goes up to the third year and goes down after that. REER explains 1.3\%and this share goes up to the third year and goes down after that. In panel (b) for Germany, we find that after the first year the demand explains $70.2 \%$ of its variance and this share goes down after that. Income explains $13.2 \%$ and this share goes up after that. Price explains $3.6 \%$ and this share goes up after that. REER explains $12.9 \%$ and this share goes up to the fourth year and goes down after that. In panel (c) for Netherlands, after the first year the demand explains $94.4 \%$ of its variance and this share goes down after that. Income explains $4.2 \%$ and this share goes down after that. Price explains $0.03 \%$ and this share goes up after that. REER explains $1.1 \%$ and this share goes up to the third year and goes down after that. In panel (d) for UK, after the first year the demand explains $63.3 \%$ of its variance and this share goes down after that. Income explains $23.6 \%$ and this share goes up after that. Price explains $4.1 \%$ and this share goes up to the third year and goes down after that. REER explains $8.9 \%$ and this share goes up to the fourth year and goes down after that. In panel (e) for US, after the first year the demand explains $73.5 \%$ of its variance and this share goes after that. Income explains $26.2 \%$ and this share goes up after that. Price explains $0.09 \%$ and this share goes up to the third year and goes down after that. REER explains $0.13 \%$ and this share goes up to the third year and goes down after that. This means that the most important variable in explaining the demand variance after the demand himself and the income. We can conclude from these two tests the two important factors in demand for tourism are the tourists' experiences and their income and there is a weak role for prices.

\section{Conclusion}

In this article we studied the determinants of inbound tourism demand in Turkey over the annual period 1986-2012. We conducted ADF (Augmented Dickey-Fuller) and PP(Philips and Perron) tests for stationary to determine the level of integration. We used autoregressive distributed lag (ARDL) approach to test for cointegration and the (bounds test)developed by Pesaran et al. (2001). We estimated long run model using OLS and estimated general error correction model. The results indicate that the most significant factor determining inbound tourist flows is the real per capita income (with long run elasticities between 1.7 and 0.02 and short run elasticities between 1.310 and -0.05 ) and real effective exchange (with long run elasticities between -1.09 and -7.06 and short run elasticities between 0 and 6.13).We found weak effects for price. For the special events the political events played a strong role differed from country to country. The most important one was D1 which affected the whole markets, as they participated in the gulf war 1991. Considering the Abdullah Öcalan arresting and the followed political instability 1999, D2,it affected France, Germany and Netherlands, because in these countries there are a large number of migrants from Turkey. Also Iraq invasion (D4) had negative effect in US only because only US government directly took a role in the war. There was no role and financial crisis. In impulse response and variance decomposition we found that the most important factors are demand himself and income. This means that the factors which should be observed by Turkish planers and tourism business accurately are the quality of tourism services and real per capita income in the origin country and real effective exchange rate in the origin country, and domestic and regional political events. Also this suggests that the policy of low prices may not be effective in tourism marketing for Turkey. As there were so many differences between countries we expect that it will be better, when there is enough data, to study the demand behavior by dividing the demand for tourism by the motivation of tourists.

\section{References:}

Akls, S. (1998). A compact econometric model of tourism demand for Turkey. Tourism Management, 19(1), 99-102.

Balli, F., Balli, H. O. \& Cebeci, K. (2013). Impacts of exported Turkish soap operas and visa-free entry on inbound tourism to Turkey. Tourism Management, 37, 186-192.

Chaitip, P. \& Chaiboonsri, C. (2009). Thailand International Tourism Demand: the ARDL Approach to Cointegration. Annals of the University of Petroşani Economics, 9(3), 163-184

Çımat, A. \& Bahar, O. (2003). An Assessment of Tourism Sector and its Significance in the Turkish Economy. Akdeniziibf Dergisi, (6), 87-112

Dougan, J. W. (2007). Analysis of Japanese Tourist Demand to Guam. Asia Pacific Journal of Tourism Research, 12(2), 79-88.

Dwyer, L. \& Forsyth, P. (2006). International Handbook on the Economics of Tourism, Edward Elgar, U K.

Hamadeh, M. \& Khoueiri, R. (2012). Estimation the demand for tourism in Lebanon. International Journal of Business and Economics Perspectives, 7(1), 117-127.

Hill, R., Carter, G., William, E. \& Lim, G. C. (2011). Principles of econometrics $4^{\text {th }}$ Ed. John Wiley \& Sons, Inc. 
Kar, M., Zorkirişçi, E. \& Yıldırım, M. (2004). An Empirical Evaluation of the Contribution of Tourism to the Economy. Akdeniziibf Dergisi, 8, 1-18

Lee, K. N. (2011). Forecasting long-haul tourism demand for Hong Kong using error correction models. Applied Economics, 43, 527-549.

Lee, K. N. H. (2011). Estimating demand elasticities for intra-regional tourist arrivals to Hong Kong - the 'bounds' testing approach. Applied Economics Letters, 18, 1645-1654.

Munoz, T. G. (2007). German demand for tourism in Spain. Tourism Management, 28,12-22

Pesaran, M. H., Shin, Y. \& Smith, R. J. (2001). Bound testing approach to analysis of level relationships. Journal of applied Econometrics, 16, 289-326

Qu, H. \& Or, Y. S. (2006). Determinants of the Travel Demand Model for Canadian Tourists to the U.S. International Journal of Hospitality \& Tourism Administration, 7(4), 1-19.

Saray, M. O. \& Karagoz, K. (2010). Determinants of tourist inflow in Turkey: evidence from Panel gravity model. ZKU Journal of Social Sciences, 6(11), 33-46.

Song H., Witt S. F. \& Li, G. (2009). The Advanced Econometrics of Tourism Demand, 1th ed. Routledge, New York.

Turkish Hotelier Federation. (2013). Tourism report.

UNWTO. ( 2014). World Tourism Barometer, 12.

Uysal, M. \& Crompton, J. L. (1984). Determinants of Demand for International Tourist Flows to Turkey. Tourism management, 2, 288-297

Ünlüönen, K. \& Tayfan, A. (2009). The Place of Tourism in Turkish Economy. Electronic Journal of Social Sciences, 27(8), 1278-1304

Vanegas, S. M. (2009). Tourism Demand Response by Residents of Latin American Countries. International Journal of Tourism Research, 11, 17-29.

Vogt, M. G. (2008). Determinants of the demand for US exports and imports of tourism. Applied Economics, 40, 667-672.

Vogt, M. G. \& Wittayakorn, C. (1998), Determinants of the demand for Thailand's exports of tourism. Applied Economics, 30(6), 711-715.

Wang, Y. (2009). The impact of crisis events and macroeconomic activity on Taiwan's international inbound tourism demand. Tourism Management, 30, 75-82.

Zhang, Y., Qu, H. \& Tavitiyaman, P. (2009). The Determinants of the Travel Demand on International Tourist Arrivals to Thailand. Asia Pacific Journal of Tourism Research, 14(1), 77-92.

Ziramba, E. \& Moyo, B. (2013). Aggregate Outbound Tourism Demand in South Africa: an Econometric Analysis. Journal of Economics and Behavioral Studies, 5(5), 260-267.

Appendix:

Table 1: stationary test results

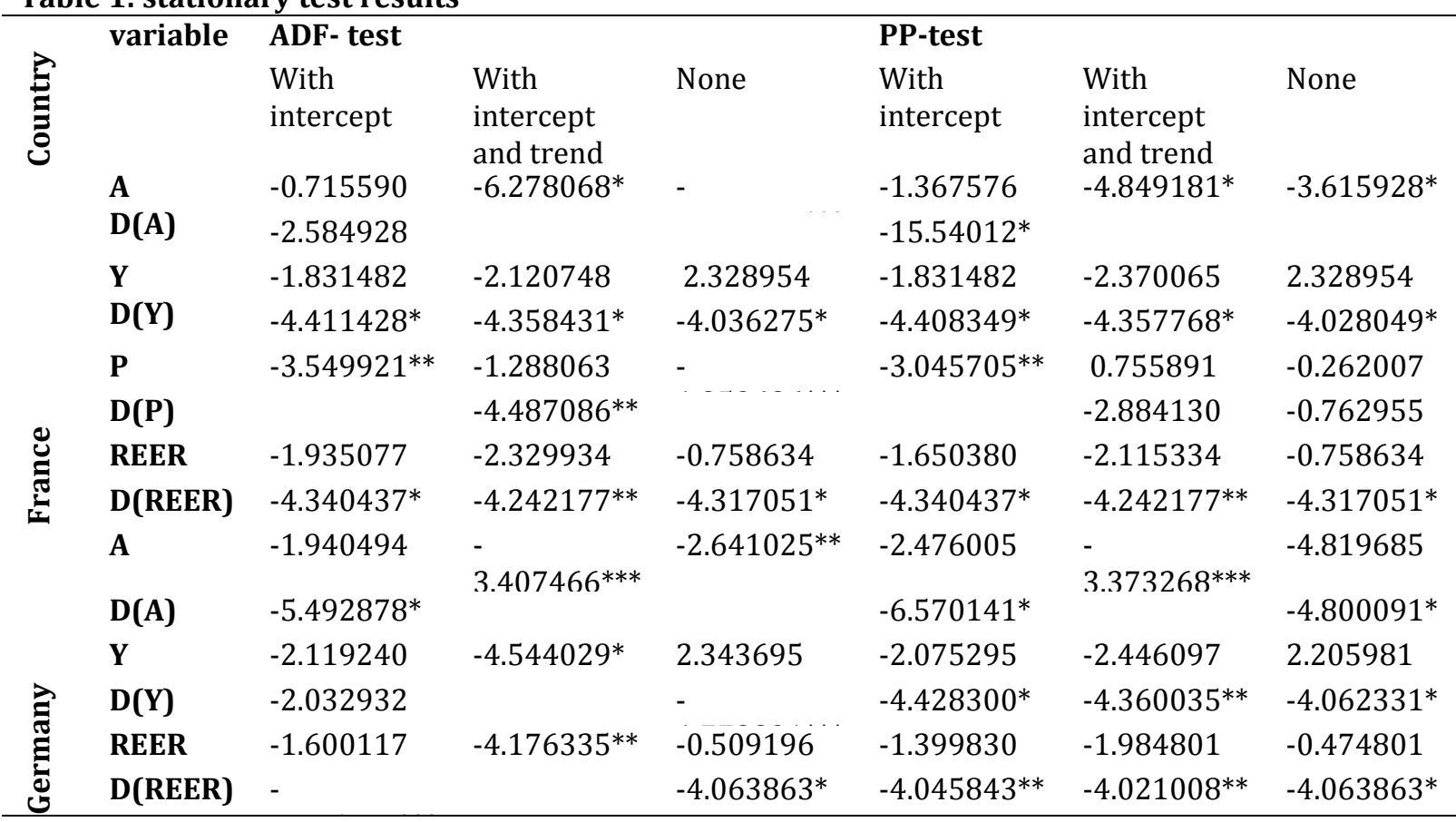




\begin{tabular}{|c|c|c|c|c|c|c|c|}
\hline \multirow{6}{*}{ 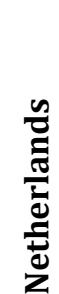 } & $\bar{A}$ & -1.925768 & -2.373433 & $-2.971742^{*}$ & -2.134885 & -2.373433 & $-3.672768^{*}$ \\
\hline & $\mathrm{D}(\mathrm{A})$ & $-5.936830^{*}$ & $-6.290619 *$ & & $-5.936830^{*}$ & $-6.376564^{*}$ & \\
\hline & $\mathbf{Y}$ & -1.703255 & $-4.389045^{* *}$ & 2.748028 & -1.699267 & -2.178113 & 2.761288 \\
\hline & $D(Y)$ & $-4.511602^{*}$ & & -1.597859 & $-4.497940^{*}$ & $-4.473456^{*}$ & $-3.917919^{*}$ \\
\hline & REER & -2.174502 & -2.256120 & -0.165809 & -2.256120 & -2.256120 & -0.166375 \\
\hline & D(REER) & $-4.461881^{*}$ & $-4.372880 *$ & $-4.552313^{*}$ & $-4.471482^{*}$ & $-4.383996 *$ & $-4.560483^{*}$ \\
\hline \multirow{7}{*}{ 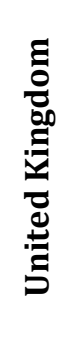 } & A & -1.843009 & $-4.964620^{*}$ & $-2.505306^{* *}$ & -1.819642 & - & - \\
\hline & $\mathrm{D}(\mathrm{A})$ & $-4.461207^{* *}$ & & & $-4.461315^{*}$ & & \\
\hline & $\mathbf{Y}$ & -2.492838 & -2.786766 & 2.765358 & -2.367172 & -2.507057 & 2.765358 \\
\hline & $D(Y)$ & $-3.943616^{*}$ & $-3.996278^{* *}$ & $-3.519225^{*}$ & $3.890655^{*}$ & $-3.974250^{* *}$ & $-3.466020^{*}$ \\
\hline & REER & -2.608651 & -2.643445 & 0.308669 & -2.084058 & -2.003365 & 0.308669 \\
\hline & D(REER) & $-3.692554^{* *}$ & $-3.650557^{* *}$ & $-3.754966^{*}$ & -3.673628 & $-3.632987^{* *}$ & $-3.734387^{*}$ \\
\hline & A & -1.661321 & -3.186635 & -1.090822 & -2.174016 & - & - \\
\hline \multirow{5}{*}{ 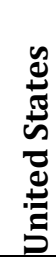 } & $D(A)$ & $-5.300515^{*}$ & $-5.175026^{*}$ & $-5.225126^{*}$ & $-6.768301^{*}$ & & \\
\hline & $\mathbf{Y}$ & -1.612892 & -2.114096 & 2.347628 & - & -1.194554 & 7.284715 \\
\hline & $D(Y)$ & - & -3.180256 & -1.287845 & & - & -1.126809 \\
\hline & REER & - & -2.658774 & -1.131851 & -2.126943 & -2.054635 & -1.131851 \\
\hline & D(REER) & & $-4.252699 * *$ & $-4.454057^{*}$ & $-4.355403^{*}$ & $-4.249582^{* *}$ & $-4.490610^{*}$ \\
\hline
\end{tabular}

Table 2: Breusch-Godfrey Serial Correlation LM Test

Panel (a)Breusch-Godfrey Serial Correlation LM Test for ARDL model

\begin{tabular}{lllll}
\hline France & F-statistic & 1.572126 & $\mathrm{~F}(2,12)$ & Prob. 0.2475 \\
Germany & Obs*R-squared & 5.190503 & Chi-Square(2) & Prob. 0.0746 \\
& F-statistic & 0.671897 & $\mathrm{~F}(2,14)$ & Prob. 0.5265 \\
\multirow{2}{*}{ Netherlands } & Obs*R-squared & 2.189476 & Chi-Square(2) & Prob. 0.3346 \\
& F-statistic & 0.412394 & F(2,14) & Prob. 0.6698 \\
UK & Obs*R-squared & 1.390893 & Chi-Square(2) & Prob. 0.4989 \\
& F-statistic & 0.611071 & F(2,18) & Prob. 0.5537 \\
US & Obs*R-squared & 1.653079 & Chi-Square(2) & Prob. 0.4376 \\
& F-statistic & 0.377952 & F(2,16) & Prob. 0.6912 \\
& Obs*R-squared & 1.172931 & Chi-Square(2) & Prob. 0.5563 \\
\hline
\end{tabular}

Panel (b) Breusch-Godfrey Serial Correlation LM Test for long run model

\begin{tabular}{|c|c|c|c|c|}
\hline \multirow[t]{2}{*}{ France } & F-statistic & 0.806211 & $\mathrm{~F}(2,18)$ & Prob. 0.4620 \\
\hline & Obs*R-squared & 2.219787 & Chi-Square(2) & Prob. 0.3296 \\
\hline \multirow[t]{2}{*}{ Germany } & F-statistic & 2.937738 & $\mathrm{~F}(2,19)$ & Prob. 0.0773 \\
\hline & Obs*R-squared & 6.377280 & Chi-Square(2) & Prob. 0.0612 \\
\hline \multirow[t]{2}{*}{ Netherlands } & F-statistic & 7.979914 & $F(2,19)$ & Prob. 0.0730 \\
\hline & Obs*R-squared & 12.32601 & Chi-Square(2) & Prob. 0.0561 \\
\hline \multirow[t]{2}{*}{ UK } & F-statistic & 1.422590 & $\mathrm{~F}(2,20)$ & Prob. 0.2645 \\
\hline & Obs*R-squared & 3.362628 & Chi-Square(2) & Prob. 0.1861 \\
\hline \multirow[t]{2}{*}{ US } & F-statistic & 0.917675 & $F(2,18)$ & Prob. 0.4173 \\
\hline & Obs*R-squared & 2.498289 & Chi-Square(2) & Prob. 0.2868 \\
\hline \multicolumn{5}{|c|}{ Panel (c) Breusch-Godfrey Serial Correlation LM Test for error correction model } \\
\hline \multirow[t]{2}{*}{ France } & F-statistic & 0.230195 & $\mathrm{~F}(2,18)$ & Prob. 0.7971 \\
\hline & Obs*R-squared & 0.744467 & Chi-Square(2) & Prob. 0.6892 \\
\hline \multirow[t]{2}{*}{ Germany } & F-statistic & 1.360678 & $\mathrm{~F}(2,17)$ & Prob. 0.2830 \\
\hline & Obs*R-squared & 3.449758 & Chi-Square(2) & Prob. 0.1782 \\
\hline \multirow[t]{2}{*}{ Netherlands } & F-statistic & 7.979914 & $\mathrm{~F}(2,17)$ & Prob. 0.2447 \\
\hline & Obs*R-squared & 12.32601 & Chi-Square(2) & Prob. 0.1217 \\
\hline UK & F-statistic & 2.286380 & $\mathrm{~F}(2,21)$ & Prob. 0.1264 \\
\hline
\end{tabular}




\begin{tabular}{|c|c|c|c|c|}
\hline US & $\begin{array}{l}\text { Obs*R-squared } \\
\text { F-statistic } \\
\text { Obs*R-squared }\end{array}$ & $\begin{array}{l}4.649156 \\
3.108729 \\
6.410396 \\
\end{array}$ & $\begin{array}{l}\text { Chi-Square(2) } \\
\mathrm{F}(2,19) \\
\text { Chi-Square(2) }\end{array}$ & $\begin{array}{l}\text { Prob. } 0.0978 \\
\text { Prob. } 0.0679 \\
\text { Prob. } 0.0626 \\
\end{array}$ \\
\hline Country & Test Statistic & Value & df & Probability \\
\hline France & $\begin{array}{l}\text { F-statistic } \\
\text { Chi-square }\end{array}$ & $\begin{array}{l}17.91730 \\
71.66921\end{array}$ & $\begin{array}{l}(4,14) \\
4\end{array}$ & $\begin{array}{l}0.0000 \\
0.0000\end{array}$ \\
\hline Germany & $\begin{array}{l}\text { F-statistic } \\
\text { Chi-square }\end{array}$ & $\begin{array}{l}15.33079 \\
61.32317\end{array}$ & $\begin{array}{l}(4,16) \\
4\end{array}$ & $\begin{array}{l}0.0000 \\
0.0000\end{array}$ \\
\hline Netherland & $\begin{array}{l}\text { F-statistic } \\
\text { Chi-square }\end{array}$ & $\begin{array}{l}16.25904 \\
65.03617\end{array}$ & $\begin{array}{l}(4,16) \\
4\end{array}$ & $\begin{array}{l}0.0000 \\
0.0000\end{array}$ \\
\hline UK & $\begin{array}{l}\text { F-statistic } \\
\text { Chi-square }\end{array}$ & $\begin{array}{l}8.885829 \\
35.54331\end{array}$ & $\begin{array}{l}(4,20) \\
4\end{array}$ & $\begin{array}{l}0.0003 \\
0.0000\end{array}$ \\
\hline US & $\begin{array}{l}\text { F-statistic } \\
\text { Chi-square }\end{array}$ & $\begin{array}{l}21.91842 \\
87.67366 \\
\end{array}$ & $\begin{array}{l}(4,18) \\
4\end{array}$ & $\begin{array}{l}0.0003 \\
0.0000 \\
\end{array}$ \\
\hline
\end{tabular}

Table 4: variance decomposition

Panel (a) France

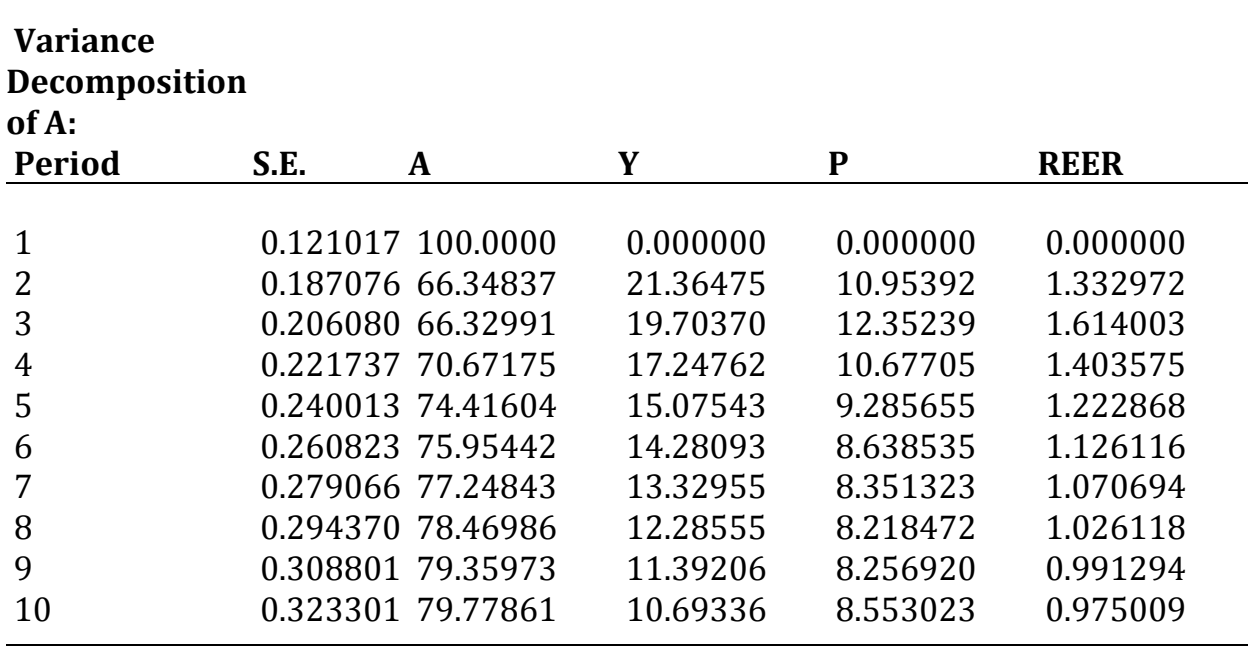

Panel (b) Germany

\begin{tabular}{|c|c|c|c|c|c|}
\hline \multicolumn{6}{|c|}{$\begin{array}{l}\text { Variance } \\
\text { Decompositi } \\
\text { on of A: }\end{array}$} \\
\hline 1 & 0.115610 & 100.0000 & 0.000000 & 0.000000 & 0.000000 \\
\hline 2 & 0.178369 & 70.21139 & 13.21827 & 3.611993 & 12.95834 \\
\hline 3 & 0.190778 & 66.22858 & 14.44218 & 5.894030 & 13.43521 \\
\hline 4 & 0.196139 & 63.21715 & 16.45559 & 7.304486 & 13.02278 \\
\hline 5 & 0.212779 & 54.19084 & 24.38753 & 10.33992 & 11.08171 \\
\hline 6 & 0.232573 & 45.71583 & 31.11959 & 13.73082 & 9.433762 \\
\hline 7 & 0.252397 & 40.45888 & 34.03012 & 15.89795 & 9.613048 \\
\hline 8 & 0.276140 & 35.25552 & 37.40656 & 17.89725 & 9.440670 \\
\hline 9 & 0.303408 & 30.96686 & 40.46906 & 19.83927 & 8.724815 \\
\hline 10 & 0.331470 & 28.49956 & 41.80430 & 21.12351 & 8.572627 \\
\hline
\end{tabular}


Panel (c) Netherlands

Variance Decomposition of

A:

\begin{tabular}{llcccc} 
Period & S.E. & A & Y & P & REER \\
\hline 1 & & & & & \\
2 & 0.276870 & 100.0000 & 0.000000 & 0.000000 & 0.000000 \\
3 & 0.346290 & 94.49926 & 4.274176 & 0.030614 & 1.195946 \\
4 & 0.393995 & 92.47400 & 3.332882 & 2.631253 & 1.561867 \\
5 & 0.432438 & 93.61232 & 2.768140 & 2.282287 & 1.337255 \\
6 & 0.479094 & 94.31023 & 2.415193 & 2.148209 & 1.126370 \\
7 & 0.520678 & 93.66153 & 2.253894 & 3.101210 & 0.983368 \\
8 & 0.550228 & 92.51732 & 2.236480 & 4.329675 & 0.916525 \\
9 & 0.577391 & 90.88927 & 2.246483 & 6.015890 & 0.848358 \\
10 & 0.605046 & 88.40475 & 2.393970 & 8.399195 & 0.802086 \\
& 0.632845 & 85.40237 & 2.547439 & 11.27656 & 0.773635 \\
\hline
\end{tabular}

Panel (d) UK

\begin{tabular}{llllll}
$\begin{array}{l}\text { Variance } \\
\text { Decompositi } \\
\text { on of A: } \\
\text { Period }\end{array}$ & S.E. & A & Y & P & \\
\hline & & & & & \\
1 & 0.076180 & 100.0000 & 0.000000 & 0.000000 & 0.000000 \\
2 & 0.095864 & 63.34105 & 23.64562 & 4.110056 & 8.903274 \\
3 & 0.140756 & 36.57898 & 25.48305 & 10.78797 & 27.15000 \\
4 & 0.181148 & 31.37030 & 27.54937 & 9.765808 & 31.31452 \\
5 & 0.216362 & 32.25386 & 33.93480 & 8.412975 & 25.39836 \\
6 & 0.246005 & 31.78001 & 39.07665 & 7.845377 & 21.29797 \\
7 & 0.275567 & 31.49898 & 42.74547 & 7.126421 & 18.62912 \\
8 & 0.301397 & 31.58160 & 45.23401 & 6.499276 & 16.68512 \\
9 & 0.321553 & 31.73733 & 46.71225 & 6.001448 & 15.54897 \\
10 & 0.340353 & 32.36552 & 47.36949 & 5.492739 & 14.77225 \\
& & & & & \\
\hline
\end{tabular}

Panel (e) US

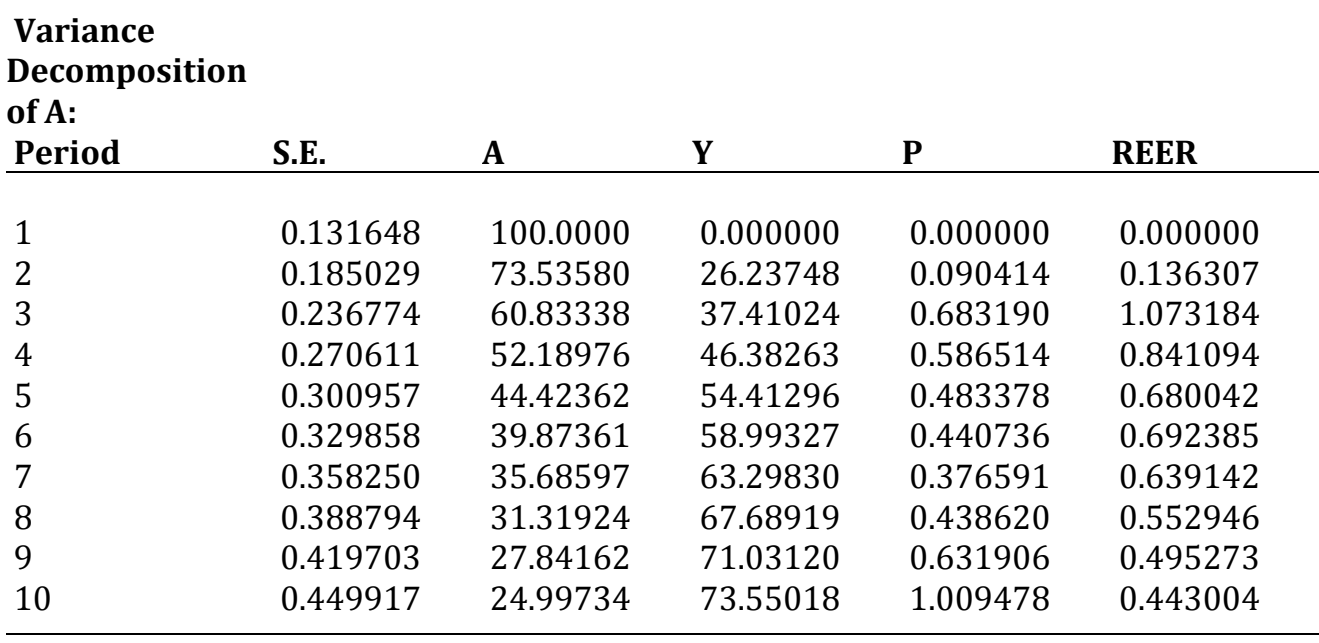


Figure 1: CUSUM stability test

Panel (a) CUSUM stability test results for ARDL model
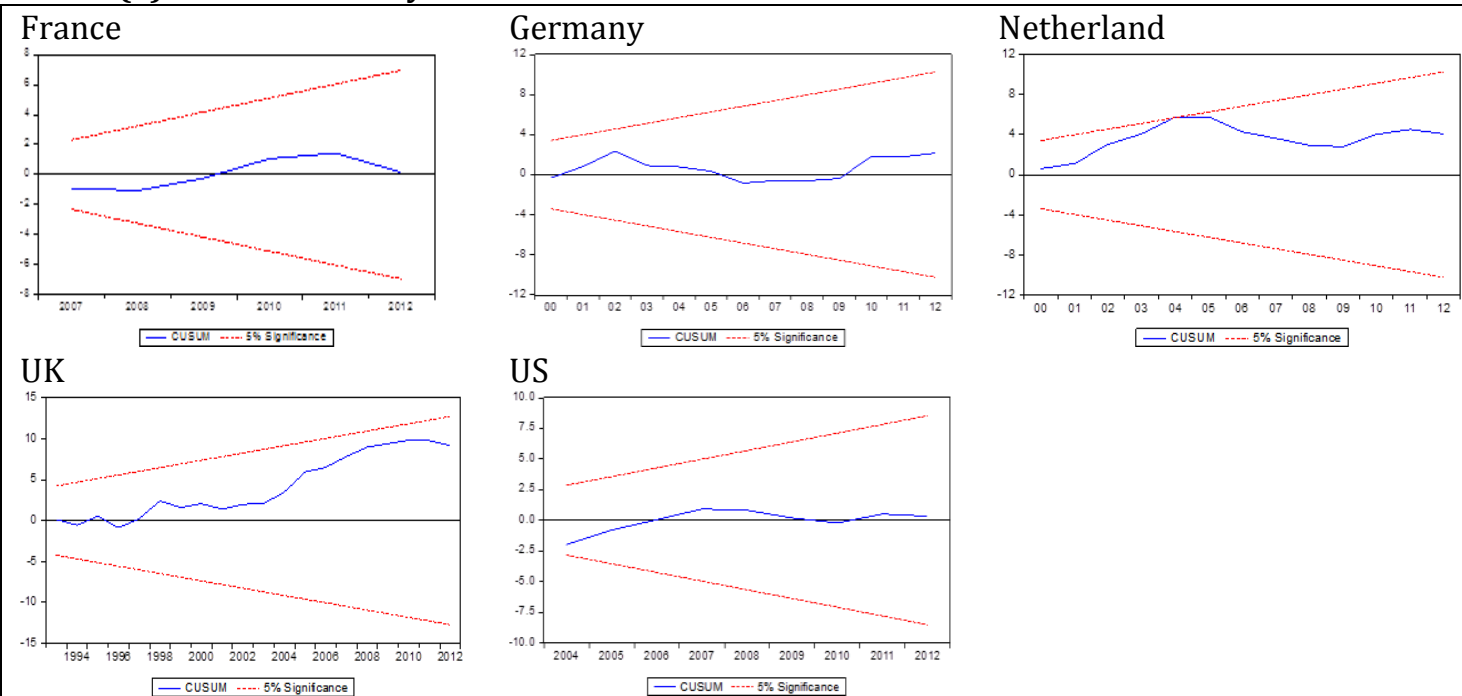

US

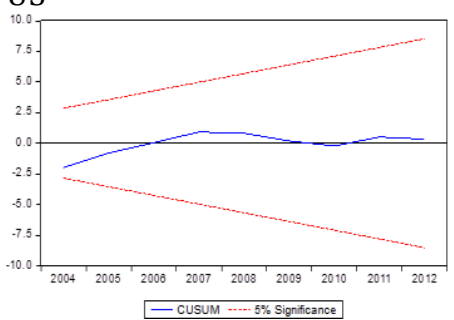

\section{Panel (b) CUSUM stability test results for long run model}
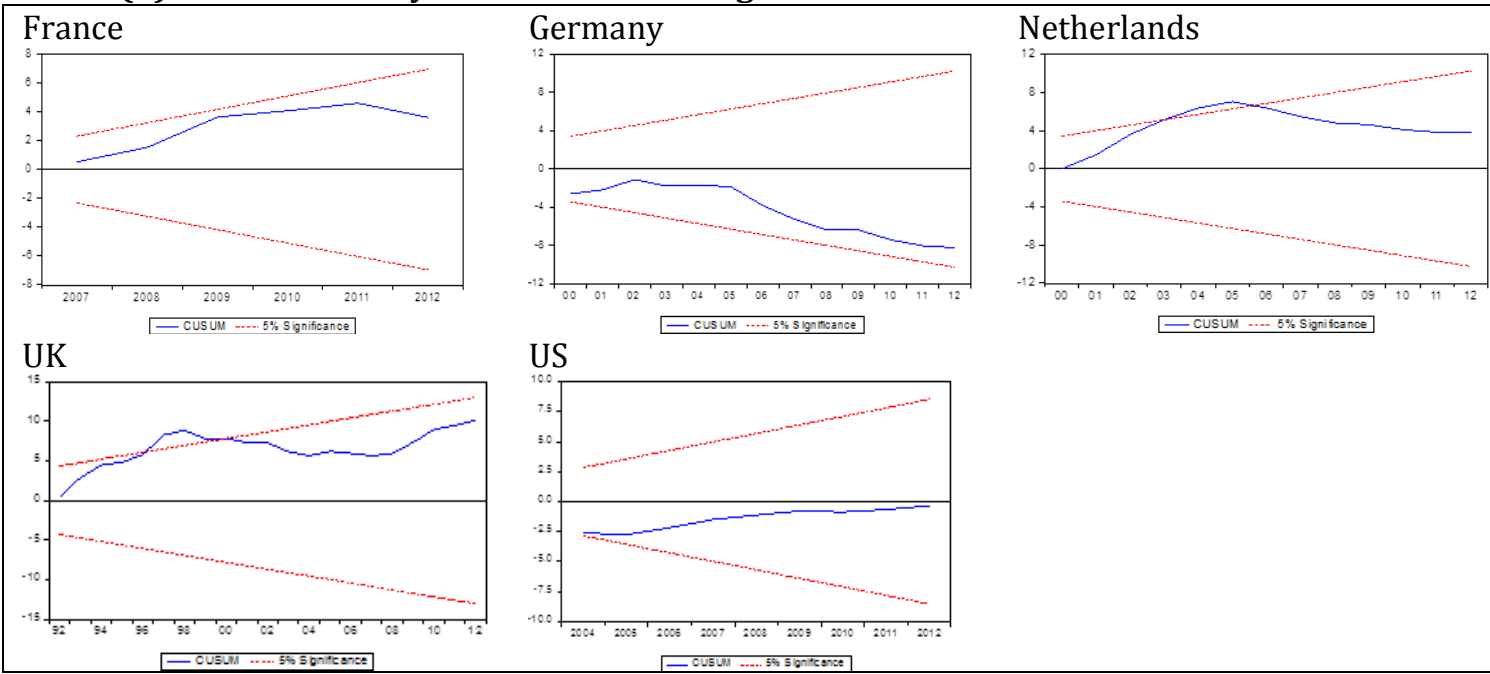

Panel (c) CUSUM stability test results for error correction model
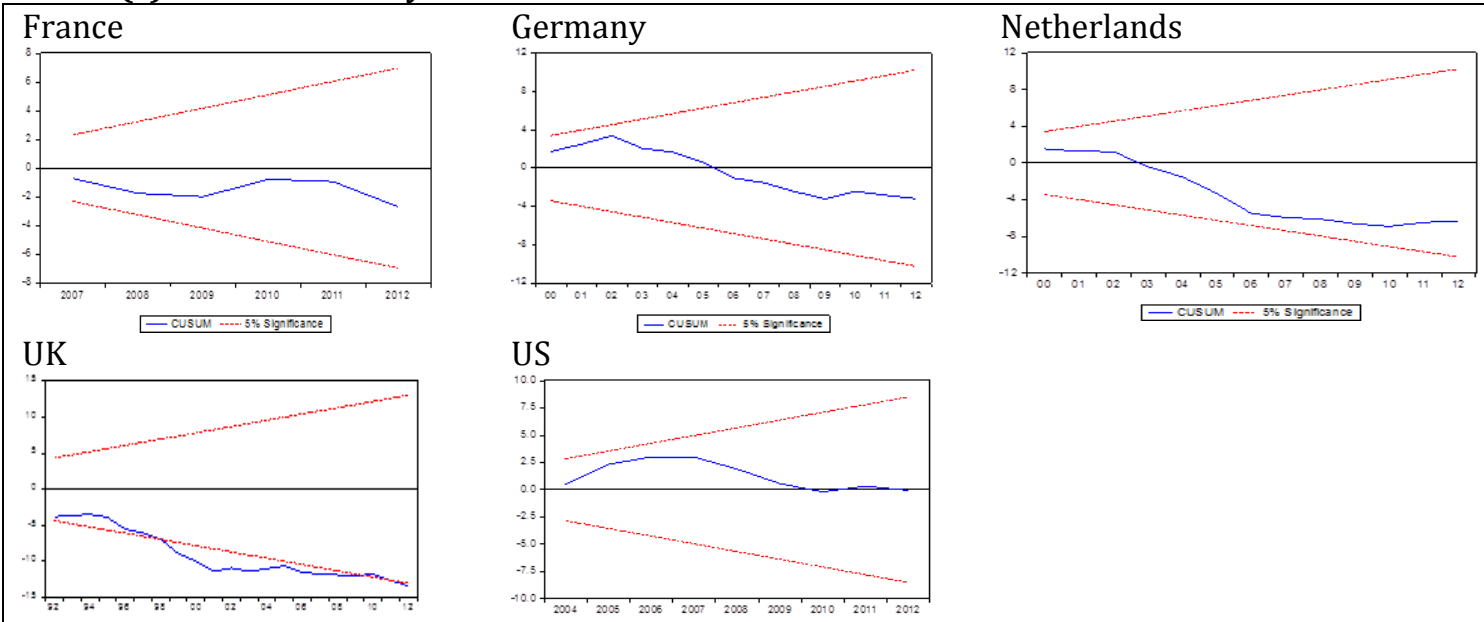

US

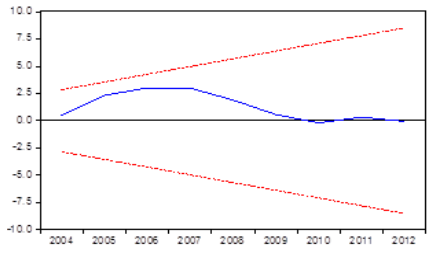
- CuSUM … 5\% s g gnticance 
Figure 2: Impulse Response

\section{Panel (a) France}

Response of A to Cholesky

One S.D. Innovations

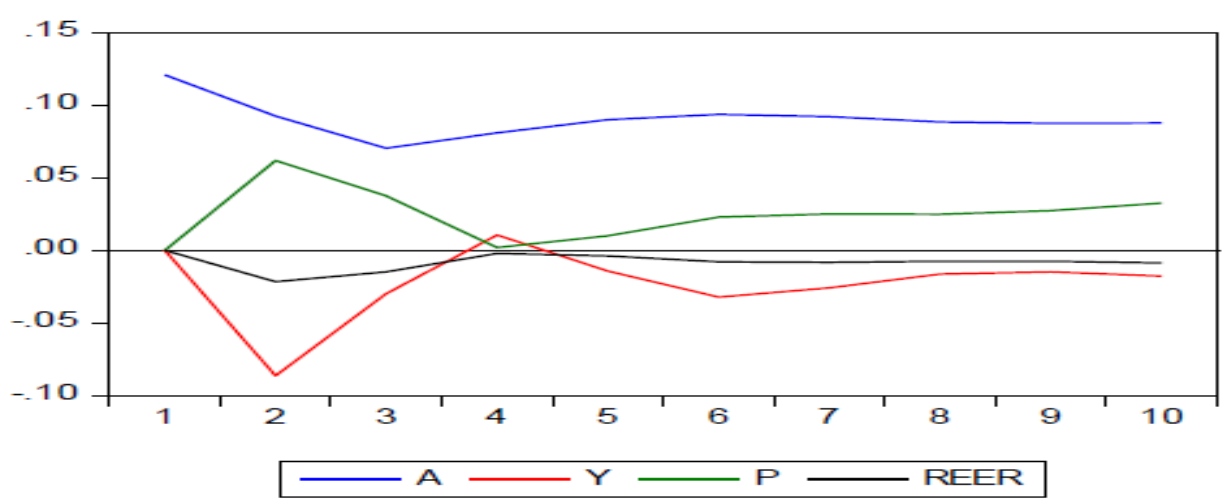

Panel (b) Germany

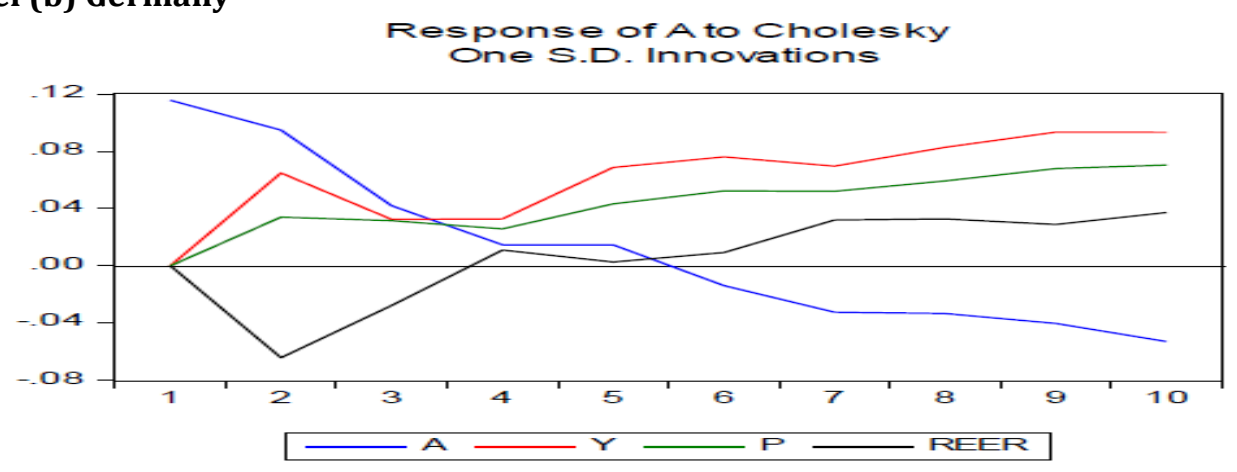

Panel (c) Netherlands

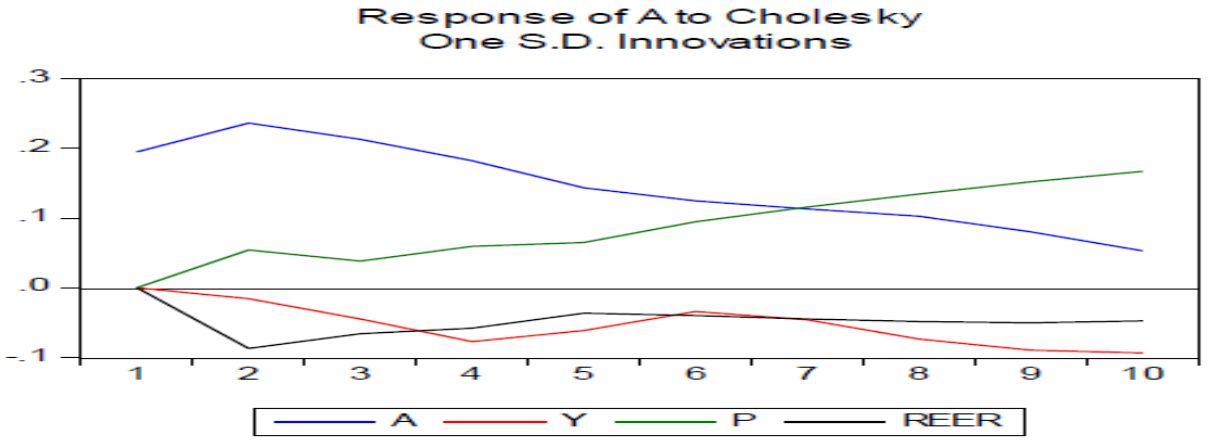

Panel (d) UK

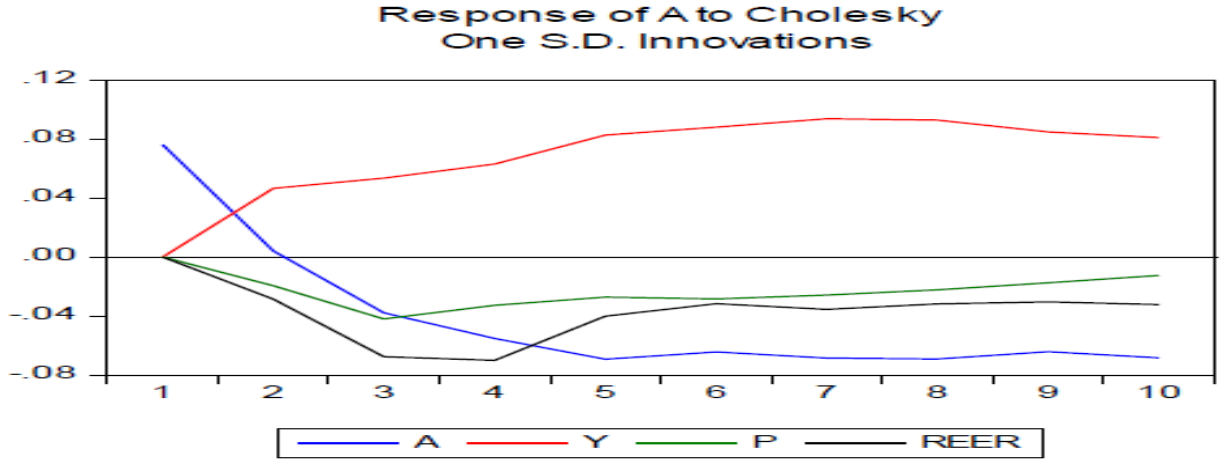


Panel (e) US

Response of A to Cholesky

one S.D. Innovations

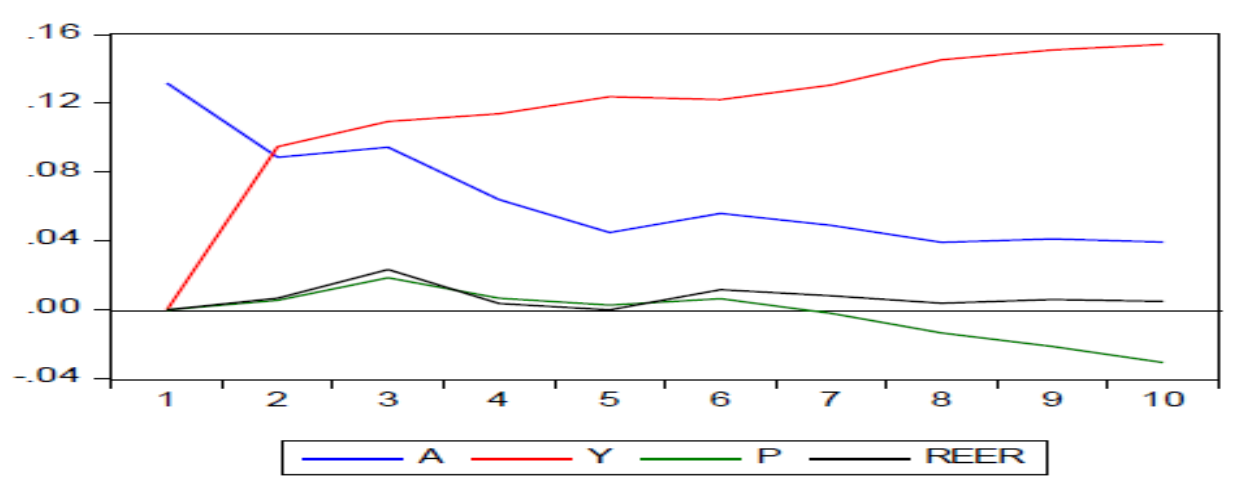

